\title{
混合型・成層型貯水池での潜入密度流の 水理特性について \\ FLOW CAHACTERISTICS OF PLUNGE FLOWS IN WELL-MIXED AND STRATIFIED RESERVOIRS
}

\author{
秋山壽一郎 ${ }^{1} \cdot$ 片山哲幸 $^{2} \cdot$ 西 $\quad$ 恭太 $^{2} \cdot$ 土居正明 ${ }^{2}$ \\ Juichiro AKIYAMA, Tetuyuki KATAYAMA, Kyouta NISHI and Masaaki DOI \\ ${ }^{1}$ 正会員 Ph. D 九州工業大学教授 工学部建設社会工学科（广804-8550北九州市戸畑区仙水町1-1） \\ 2学生員 九州工業大学大学院 工学研究科博士前期課程 （同上）
}

\begin{abstract}
Flow characteristics of plunge flows in well-mixed and stratified reservoirs are investigated experimentally. The study is directed towards the estimation of the densimetric Froude number $F_{p}$ at the plunge point and the initial mixing rate $\gamma$. The internal critical slope $I_{c}$ is found to be about $1 / 50$. It is shown that the values of $F_{p}$ in well-mixed reservoirs are strongly affected by the inflow densimetric Froude number $\mathrm{F}_{0}$ and the channel slope $\mathrm{I}$ when plunging takes place near the inlet of a reservoir, whereas $\mathrm{F}_{\mathrm{p}}$ becomes a constant value of 0.5 in both mild and steep channels when these effects are less pronounced, and that for the range of $\mathrm{I}=1 / 150 \sim 1 / 30$ is quantifed as a linear function of $\mathrm{I}$. It is also found that the values of $F_{p}$ in well-mixed reservoirs with a steep channel are also well approximated as 0.5 when $\mathrm{F}_{0}$ is more than about 2.0.
\end{abstract}

Key Words: reservoir, density current, plunge flow, water quality, initial mixing

\section{1. はじめに}

湖沼やダム貯水池のような閉鎖性水域の水質は流 入・流出水の影響を受ける1)。この傾向は貯水池で特に 強い. 出水時の濁質や温度差のため, 負の浮力をもった 河川水が池内に流入すると, 貯水池上流端で表層水に潜 り込む，いわゆる潜入現象が発生する.この潜入現象は, 赤潮物質の集積機構や流入濁水の挙動等の貯水池におけ る様々な水質問題と深く関わっている. このため, 数多 くの研究がこれまでなされてきた. 淡水赤潮と潜入密度 流との関係について調べた研究に限ってみても, 現地観 測や多層モデルに基づく数值解析など枚挙にいとまがな (2) 7). しかし, 後述するように, 潜入密度流の水理特 性が必ずしも充分に解明されているわけではない.

潜入密度流の流動特性量としては, 潜入水深 $\mathrm{h}_{\mathrm{p}}$, 初期 混合量, 潜入区間長 $\mathrm{x}_{\mathrm{n}}$, 界面形状などがあるが，その中 でも特に潜入水深と初期混合量が重要である. 初期混合 量については，2 層流モデルに基づき，連行係数を用い て算定する方法例之将8，潜入密度流領域での周囲水の単 位幅当たりの総連行量 $q_{\mathrm{e}}$ として捉え, 初期混合率 $\gamma$ で評 価する方法がある. 後者は実用的である等の理由で, こ れまで多くの研究で，これが用いられている(例えは99) 13). 本研究でもこの定義を用いる.

等幅矩形断面水路では， $h_{p}$ と $\gamma$ はそれぞれ式(1) と
式(2)のように定義される．ここに， $\mathrm{F}_{\mathrm{p}}$ =潜入点での内 部Froude数 $\left(=\left(\mathrm{q}_{0}{ }^{2} / \varepsilon_{0} g \mathrm{gh}_{\mathrm{p}}{ }^{3}\right)^{1 / 2}\right)$ および $\mathrm{h}_{\mathrm{c}}=$ 内部限界水深 $\left(=\left(\mathrm{q}_{0}{ }^{2} / \varepsilon_{0} \mathrm{~g}\right)^{1 / 3}\right)$ である.ここで, $\mathrm{q}_{0}=$ 単位幅流入流量, $\varepsilon_{0}=\left(\rho_{0}-\rho_{\mathrm{a}}\right) / \rho_{\mathrm{a}}, \mathrm{g}=$ 重力加速度, $\rho_{0}$ と $\rho_{\mathrm{a}}$ はそれぞれ 流入水と周囲水の密度である(図-1参照)。

$$
\mathrm{h}_{\mathrm{p}} / \mathrm{h}_{\mathrm{c}}=\mathrm{F}_{\mathrm{p}}^{-2 / 3} \quad(1) \quad ; \quad \gamma=\mathrm{q}_{\mathrm{e}} / \mathrm{q}_{0}
$$

潜入点についてはこれまで多くの研究が重ねられてい $3^{8) \sim 22)}$ ．等幅矩形断面水路を用いた室内実験データの中 から，水路床勾配との関係がわかっているデータに基 づきこれまでの知見を総括すると， $F_{p}$ はI $=1 / 60 〜 1 / 3$ の範囲で約 $0.25 \sim 1.0$ の範囲の值を取り, 平均的には $\mathrm{F}_{\mathrm{p}} \doteqdot 0.56$ 程度の值となる ${ }^{1)}$. この平均値は, Savage \& Brimberg $^{20)}$ によって理論的に得られた $\mathrm{F}_{\mathrm{p}}=0.50$ や福岡ら によって半理論的に得られた $\mathrm{F}_{\mathrm{p}} \doteqdot 0.50$ に近い. 有田・塚 原 ${ }^{21)}$ も $\mathrm{I}=1 / 50$ 程度では $\mathrm{F}_{\mathrm{p}} \fallingdotseq 0.50$ で近似できると指摘して いる. また, Akiyama \& Stefan ${ }^{11), 12)}$ は, 等幅矩形断面水 路ではないが，片側の側壁の拡がり角度が $1^{\circ} \sim 7^{\circ}$ の範 囲での水平漸拡水路での $\mathrm{F}_{\mathrm{p}}$ 值は, 流入水路幅と潜入点の 水路幅が充分大きくなると， $\mathrm{F}_{\mathrm{p}} \doteqdot 0.50$ になることを示し ている。このように，ある条件が満たされれば， $\mathrm{F}_{\mathrm{p}} \doteqdot 0.50$ になると推察される. しかし, 害際には, 福岡 $ら^{8)}$ の実験結果では $\mathrm{I}=1 / 60 て ゙ \mathrm{~F}_{\mathrm{p}}=0.38 \sim 0.65$, 有田・塚 
表-1A 実験条件

\begin{tabular}{|c|c|c|c|c|c|c|c|}
\hline CASE & I & $\begin{array}{c}\mathrm{h}_{0} \\
(\mathrm{~cm}) \\
\end{array}$ & $\varepsilon_{0}$ & $\begin{array}{c}\mathrm{q}_{0} \\
\left(\mathrm{~cm}^{2} / \mathrm{s}\right)\end{array}$ & $\begin{array}{c}\mathrm{h}_{\mathrm{p}} \\
(\mathrm{cm})\end{array}$ & $\mathrm{F}_{0}$ & $F_{p}$ \\
\hline A-1-1-1 & \multirow{9}{*}{$1 / 30$} & \multirow{9}{*}{5.0} & \multirow{3}{*}{0.0007} & 10 & 7.4 & 1.08 & 0.62 \\
\hline A-1-1-2 & & & & 12.5 & 8.6 & 1.35 & 0.62 \\
\hline A-1-1-3 & & & & 15 & 9.8 & 1.62 & 0.60 \\
\hline A-1-2-1 & & & \multirow{3}{*}{0.0012} & 15 & 8.0 & 1.24 & 0.61 \\
\hline A-1-2-2 & & & & 17.5 & 9.0 & 1.44 & 0.60 \\
\hline A-1-2-3 & & & & 20 & 9.9 & 1.65 & 0.59 \\
\hline A-1-3-1 & & & \multirow{3}{*}{0.00175} & 15 & 7.1 & 1.02 & 0.61 \\
\hline A-1-3-2 & & & & 17.5 & 7.85 & 1.20 & 0.60 \\
\hline A-1-3-3 & & & & 20 & 8.6 & 1.37 & 0.62 \\
\hline A-2-1-1 & \multirow{9}{*}{$1 / 50$} & \multirow{3}{*}{5.0} & \multirow{3}{*}{0.0007} & 8 & 6.6 & 0.86 & 0.57 \\
\hline A-2-1-2 & & & & 10 & 7.6 & 1.08 & 0.57 \\
\hline A-2-1-3 & & & & 12 & 9.0 & 1.30 & 0.54 \\
\hline A-2-2-1 & & \multirow{6}{*}{2.4} & \multirow{6}{*}{0.001} & 5 & 4.7 & 1.36 & 0.49 \\
\hline A-2-2-2 & & & & 7 & 5.5 & 1.90 & 0.55 \\
\hline A-2-2-3 & & & & 9 & 6.7 & 2.45 & 0.52 \\
\hline A-2-2-4 & & & & 11 & 7.8 & 2.99 & 0.51 \\
\hline A-2-2-5 & & & & 13 & 8.1 & 3.53 & 0.56 \\
\hline A-2-2-6 & & & & 15 & 9.1 & 4.08 & 0.55 \\
\hline A-3-1-1 & \multirow{9}{*}{$1 / 60$} & \multirow{3}{*}{5.0} & \multirow{3}{*}{0.0007} & 6.5 & 6.4 & 0.50 & 0.35 \\
\hline A-3-1-2 & & & & 8.0 & 7.1 & 0.50 & 0.38 \\
\hline A-3-1-3 & & & & 10 & 7.6 & 0.57 & 0.39 \\
\hline A-3-2-1 & & \multirow{6}{*}{2.4} & \multirow{6}{*}{0.001} & 5 & 4.7 & 1.36 & 0.49 \\
\hline A-3-2-2 & & & & 7 & 5.7 & 1.90 & 0.51 \\
\hline A-3-2-3 & & & & 9 & 6.5 & 2.45 & 0.55 \\
\hline A-3-2-4 & & & & 11 & 7.4 & 2.99 & 0.56 \\
\hline A-3-2-5 & & & & 13 & 8.4 & 3.53 & 0.54 \\
\hline A-3-2-6 & & & & 15 & 9.5 & 4.08 & 0.52 \\
\hline A-4-1-1 & \multirow{16}{*}{$1 / 80$} & \multirow{9}{*}{5.0} & \multirow{3}{*}{0.0007} & 4.5 & 6.1 & 0.49 & 0.36 \\
\hline A-4-1-2 & & & & 5.5 & 6.5 & 0.59 & 0.40 \\
\hline $\mathrm{A}-4-1-3$ & & & & 7.0 & 7.6 & 0.76 & 0.39 \\
\hline A-4-2-1 & & & \multirow{3}{*}{0.0012} & 7.0 & 6.3 & 0.58 & 0.42 \\
\hline$A-4-2-2$ & & & & 8.5 & 6.5 & 0.70 & 0.47 \\
\hline A-4-2-3 & & & & 10 & 7.5 & 0.82 & 0.45 \\
\hline A-4-3-1 & & & \multirow{3}{*}{0.00175} & 10 & 6.5 & 0.68 & 0.45 \\
\hline A-4-3-2 & & & & 11.5 & 6.8 & 0.79 & 0.48 \\
\hline A-4-3-3 & & & & 13 & 7.6 & 0.89 & 0.47 \\
\hline$A-4-4-1$ & & \multirow{7}{*}{2.4} & \multirow{7}{*}{0.02} & 25 & 5.0 & 1.52 & 0.50 \\
\hline$A-4-4-2$ & & & & 35 & 6.3 & 2.13 & 0.50 \\
\hline A-4-4-3 & & & & 40 & 6.7 & 2.43 & 0.52 \\
\hline $\mathrm{A}-4-4-4$ & & & & 50 & 7.5 & 3.04 & 0.55 \\
\hline A-4-4-5 & & & & 60 & 8.5 & 3.65 & 0.54 \\
\hline A-4-4-6 & & & & 65 & 9.0 & 3.95 & 0.54 \\
\hline A-4-4-7 & & & & 75 & 10.3 & 4.56 & 0.51 \\
\hline
\end{tabular}

原 ${ }^{21)}$ でも $\mathrm{I}=1 / 50$ で $\mathrm{F}_{\mathrm{p}}=0.405 \sim 0.784$ の值を取っている. Lee \& $\mathrm{Yu}^{99}$ は， I= $1 / 50$ で潜入初期にはF 安定した状態では $\mathrm{F}_{\mathrm{p}} \fallingdotseq 0.6$ 程度となると報告している. このように， $\mathrm{F}_{\mathrm{p}} \doteqdot 0.5$ となる根拠あるいは条件は必ずし も明確ではない。

$\mathrm{F}_{\mathrm{p}}$ 值がばらつく主因としては，(1)水路床勾配I と流入 内部Froude数 $\mathrm{F}_{0}\left(=\left(\mathrm{q}_{0}{ }^{2} / \varepsilon_{0} \mathrm{gh}_{0}{ }^{3}\right)^{1 / 2}\right)$ により, 流動形態が変 化するため，この影響を受けること，(2)潜入点の位置が 安定するまでに時間を要するため, 実験において必ずし も安定した潜入水深が得られているとは限らないこと，

\begin{tabular}{|c|c|c|c|c|c|c|c|}
\hline CASE & I & $\begin{array}{c}\mathrm{h}_{0} \\
(\mathrm{~cm})\end{array}$ & $\varepsilon_{0}$ & $\begin{array}{c}\mathrm{q}_{0} \\
\left(\mathrm{~cm}^{2} / \mathrm{s}\right)\end{array}$ & $\begin{array}{c}\mathrm{h}_{\mathrm{p}} \\
(\mathrm{cm})\end{array}$ & $\mathrm{F}_{0}$ & $F_{p}$ \\
\hline A-5-1-1 & \multirow{6}{*}{$1 / 110$} & \multirow{6}{*}{2.4} & \multirow{2}{*}{0.02} & 8 & 2.52 & 0.49 & 0.45 \\
\hline A-5-1-2 & & & & 15 & 3.47 & 0.91 & 0.53 \\
\hline A-5-2-1 & & & \multirow{4}{*}{0.05} & 40 & 4.99 & 1.54 & 0.51 \\
\hline A-5-2-2 & & & & 50 & 5.98 & 1.92 & 0.49 \\
\hline$A-5-2-3$ & & & & 65 & 7.02 & 2.50 & 0.50 \\
\hline A-5-2-4 & & & & 75 & 7.87 & 2.88 & 0.49 \\
\hline A-6-1-1 & \multirow{8}{*}{$1 / 150$} & \multirow{2}{*}{5.0} & \multirow{2}{*}{0.0007} & 0.75 & 5.2 & 0.08 & 0.07 \\
\hline A- $6-1-2$ & & & & 1.0 & 5.3 & 0.11 & 0.10 \\
\hline A-6-2-1 & & \multirow{6}{*}{2.4} & \multirow{2}{*}{0.01} & 3.5 & 2.8 & 0.30 & 0.24 \\
\hline A-6-2-2 & & & & 5.0 & 3.3 & 0.43 & 0.27 \\
\hline A-6-3-1 & & & \multirow{4}{*}{0.1} & 20 & 3.2 & 0.54 & 0.35 \\
\hline A-6-3-2 & & & & 35 & 4.2 & 0.95 & 0.41 \\
\hline A-6-3-3 & & & & 50 & 5.4 & 1.36 & 0.40 \\
\hline A-6-3-4 & & & & 65 & 6.2 & 1.77 & 0.42 \\
\hline
\end{tabular}

表-1B 実験条件

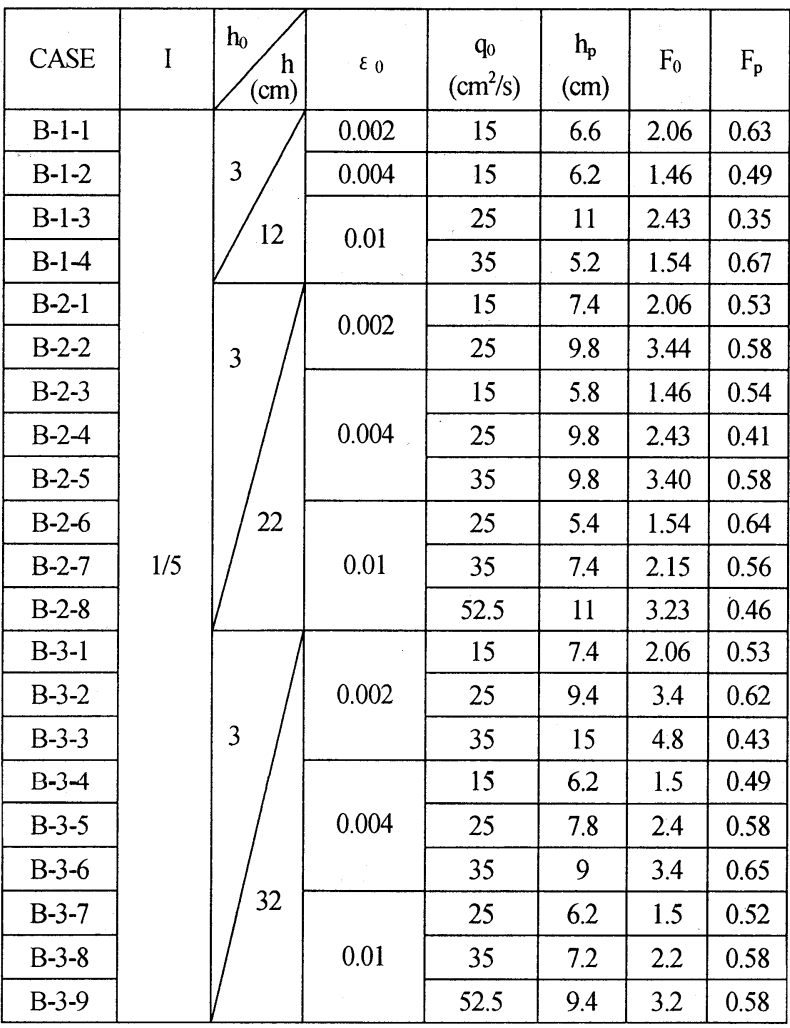

などが考えられる．著者ら ${ }^{14)}$ は，(1) $\mathrm{F}_{0}$ が充分に大きけれ ば，急勾配水路であっても $\mathrm{F}_{\mathrm{p}} \doteqdot$ 一定值になる可能性があ ること，(2) $\mathrm{F}_{0}$ が充分に大きくない場合，すなわち急勾配 水路で流入点に近い点で潜入する場合や緩勾配水路で流 入点から相当に離れた点で潜入する場合では，そこでの $\mathrm{F}_{\mathrm{p}}$ 值が大きく変化することを示した.

一方，初期混合率 $\gamma$ についは，これまでの知見を総 括寸ると, $y=0$ 約 2.00 範囲の值を取る ${ }^{1)}$. しかし，流 速あるいは密度分布形等の正確な計測が必要なこともあ り，ほとんど有益な情報は得られていない. Farre11 \& Stefan ${ }^{133}$ は, $\mathrm{k}^{-} \varepsilon$ モデルを用いた数值実験により, 潜入 密度流下流端での内部Froude数 $\mathrm{F}_{\mathrm{n}}$ との経験式として, $\mathrm{F}_{\mathrm{n}} \geqq 0.7$ で $\gamma=0.5\left(\mathrm{~F}_{\mathrm{n}}-0.7\right), \mathrm{F}_{\mathrm{n}}<0.7$ で $\gamma=0$ のように得てい る。しかし， $\gamma$ を適正に評価するためには，流速・密度 
分布を正確に再現する必要があるが，数值実験によって 得られた $\mathrm{F}_{\mathrm{p}}$ 值は彼らが行った室内実験結果とはかなり異 なっている. このため, その再現精度には疑問があると 考えられる. 著者ら ${ }^{14)}$ は， $\gamma$ と $\mathrm{F}_{0}$ やと関係を明らか にすることを目的として, 潜入密度流領域下端での流速 と密度分布を詳細に計測し，I=1/150〜1/30の範囲での $\gamma$ とIとの関係を得ている.

本研究は, 以上の背景を踏まえ, 前報(4)をさらに発展 させたものである. 特に, ここでは実際問題で重要な緩 勾配水路床での潜入密度流に関する情報が久落している ことを踏まえ, 混合型貯水池を対象に, 限界勾配から緩 勾配水路でのデータを収集し, より広範囲な水路床勾配 と流入内部Froude数での潜入点と初期混合率について検 討を加えた．また，その重要性にもかかわらず，潜入の 後に躍層に沿って中層流として貫入する成層型貯水池で の潜入現象について，有益な知見が全く得られていない ことを踏まえ, 流入流出量が比較的少なく1次躍層が強 い成層I型ダム貯水池を対象に，そこでの潜入点につい ても検討を加えた。

\section{2. 実験}

実験は，混合型貯水池での潜入密度流を対象とした CASE A，成層型貯水池において流入水が潜入を経て，中 層密度流として躍層に沿って貫入する場合の潜入密度流 を対象としたCASE Bの二通りを実施した。

CASE Aの実験装置は，前面アクリル製の水槽（長さ $9.0 \mathrm{~m}$, 深さ $1.2 \mathrm{~m}$, 幅0. $6 \mathrm{~m})$ 中に長さ $1.15 \mathrm{~m}$ の水平部と下端 部が段落ちになった傾斜部よりなる幅 $0.1 \mathrm{~m}$ の水路を設置 したものである. 貯水池部の水路床勾配 Iを $1 / 30 〜 1 / 150$ の範囲で変化させるとともに，各Iについて流入内部 Froude数 $\mathrm{F}_{0}$ を様々に変化させ実験を行った．ここに， $\mathrm{h}_{0}=$ 水平流入水路の水深である. 潜入密度流の流れの定義図 と実験条件をそれぞれ図-1Aと表-1Aに示す．CASE Bの実 験装置は，アクリル製ひ)水慒(流入水路の長さ $=1.0 \mathrm{~m}$, 貯 水池部の長さ $=2.85 \sim 3.85 \mathrm{~m}$, 媣さ $=0.12 \sim 0.32 \mathrm{~m}$, 幅 $=0.16 \mathrm{~m})$ 中にI $=1 / 5$ の斜面とその下流側に躍層を模した水 平のアクリル板を設置したものである. 下流端は段落ち となっている. 流入水路での水深 $\mathrm{h}_{0}$ を一定に保ちながら, 水平部の水深 $\mathrm{h}$ 変化させ， $\mathrm{h} / \mathrm{h}_{0}$ の影響を調べた。流れ の定義図と実験条件をそれぞれ図-1Bと表-1Bに示す。

実験・解析方法としては, CASE Aではスリット光で可 視化した潜入点近傍の流況をCCDカメラで撮影した画像 をコンピューター解析することで，潜入水深 面形状を求めた。ただし，I=1/150では水路の長さの制 約のため, $\mathrm{F}_{0}$ が充分大きなところでのデータを収集する ことはできなかった．また，潜入点から測って $30 \mathrm{~h}_{\mathrm{p}}$ の下 流での下層密度流の流速と塩分濃度分布をそれぞれサ一 マル式微流速計と導電率計を用いて計測した．流速分布 を積分することで単位幅流量 $\mathrm{q}_{\mathrm{n}}$ を得た。 さらに，それぞ れの分布形状に基づき, 後述するモーメント法で, 層平 均流速 $\mathrm{U}_{\mathrm{n}}$, 層平均有効重力 $\mathrm{B}_{\mathrm{n}}\left(=\varepsilon_{\mathrm{n}} \mathrm{g}\right)$ および層厚 $\mathrm{h}_{\mathrm{n}}$ を求め た。これらの結果に基づき, 初期混合率 $\gamma$ を, $\gamma=\mathrm{q}_{\mathrm{n}} / \mathrm{q}_{0}-1$ と $\gamma=\varepsilon_{0} / \varepsilon_{\mathrm{n}}-1$ 二通りの方法で算定した.

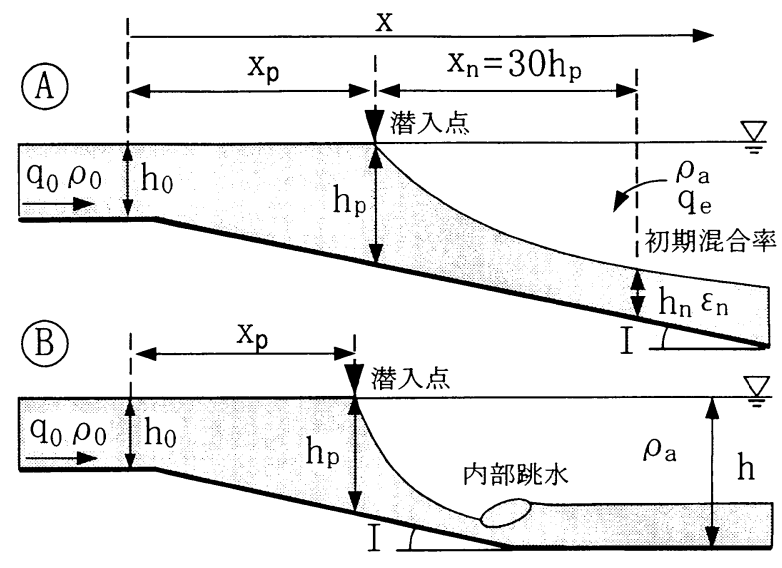

図-1＼cjkstart潜入密度流の流れの定義図 (A:混合型, B:成層型)

一方, CASE Bでは，斜面部で潜入するように流入条件 を設定し, CASE Aと同様な手法で潜入水深 $\mathrm{h}_{\mathrm{p}}$ のみを求め た. なお, 潜入点の位置は, 条件によっては時間の経過 とともにかなり移動し， $\mathrm{F}_{\mathrm{p}}$ が散らばる要因になる．特に， CASE Aの緩勾配水路では潜入点が安定するまでに, 最大 で4時間も要することがあった。このため, 本研究では 潜入点近傍の流況を常時モニターし, 安定状態に達した ことを確認した後に，全ての測定を手早く実施した.

\section{3. 実験結果}

\section{(1) 混合型貯水池での潜入密度流 (CASE A)}

図-2は，既往の室内実験結果と本研究で得られた データに基づき， $\mathrm{F}_{\mathrm{p}}$ の頻度分布を示したものである。こ れより， $\mathrm{F}_{\mathrm{p}}$ は0〜1.00可能な範囲の幅広い值を取ること

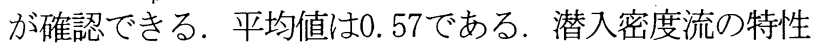
は，水路床勾配Iに依存寸る可能性があるので, 下層密 度流の限界勾配 $\mathrm{C}_{\mathrm{c}}$ がどのような值を取るのかを明確にし ておく必要がある。 ちなみに, Lee \& $\mathrm{Yu}^{9}$ は $1=1 / 50$ は緩 勾配，福岡ら舀 は $1 / 10$ は急勾配， $1 / 60$ は緩勾配としてお り，著者ら ${ }^{(4)}$ は， $I_{c} \fallingdotseq 1 / 50$ と推定した。

以下では, $\mathrm{F}_{\mathrm{n}}$ 〜の関係について若干の検討を行う。 図-3は，下層密度流の流速分布と密度分布を示したもの である.いずれも最大值と最大值を取る距離の半値半幅 で無次元化されており, 水路床勾配にかかわらず, 分布 形状はほぼ相似形であることが わかる. 図中の実線で 示した回帰曲線に基づき, 式(3)に定義するモーメント 法で，式(5)のようにU $\mathrm{U}_{\mathrm{n}}, \mathrm{B}_{\mathrm{n}}$ および $\mathrm{h}_{\mathrm{n}}$ を求め，下層密度流 のFroude数 $\mathrm{F}_{\mathrm{n}}\left(=\left(\mathrm{q}_{\mathrm{n}}{ }^{2} / \varepsilon_{\mathrm{n}} \mathrm{gh}_{\mathrm{n}}\right)^{3}{ }^{1 / 2}\right)$ を算定した. ここで, 添 字nは下層密度流の特性量であることを示す． $\mathrm{S}_{1}$ と $\mathrm{S}_{2}$ は, 式(4)で定義される形状係数であり，I=1/150～1/30の範 囲では，それぞれ約0.7と1.0であった。

$$
\begin{aligned}
& U_{\mathrm{n}} \mathrm{h}_{\mathrm{n}}=\int_{0}^{\infty} \mathrm{udy} ; \mathrm{U}_{\mathrm{n}} \mathrm{B}_{\mathrm{n}} \mathrm{h}_{\mathrm{n}}=\int_{0}^{\infty} \mathrm{ubdy} ; \mathrm{U}_{\mathrm{n}}{ }^{2} \mathrm{~h}_{\mathrm{n}}=\int_{0}^{\infty} \mathrm{u}^{2} d y(3) \\
& \text { ここに, } \mathrm{S}_{1}=\int_{0}^{\infty} 2 \text { bdy } ; \quad \mathrm{S}_{2}=\int_{0}^{\infty} \mathrm{bdy} / \mathrm{Bh} \\
& \mathrm{U}_{\mathrm{n}}=\frac{\int_{0}^{\infty} \mathrm{u}^{2} \mathrm{dy}}{\int_{0}^{\infty} \mathrm{udy}} ; \mathrm{B}_{\mathrm{n}}=\frac{\int_{0}^{\infty} \mathrm{ubdy}}{\int_{0}^{\infty} \mathrm{udy}} ; \mathrm{h}_{\mathrm{n}}=\frac{\left(\int_{0}^{\infty} \mathrm{udy}\right)^{2}}{\int_{0}^{\infty} \mathrm{u}^{2} \mathrm{dy}}
\end{aligned}
$$




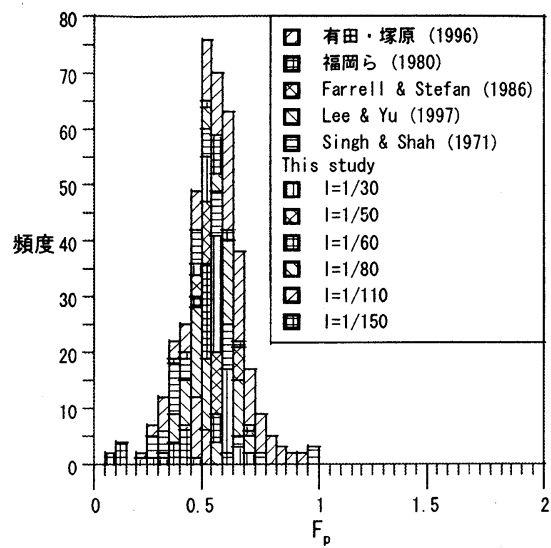

図-2 $F_{\mathrm{p}}$ 值の頻度分布

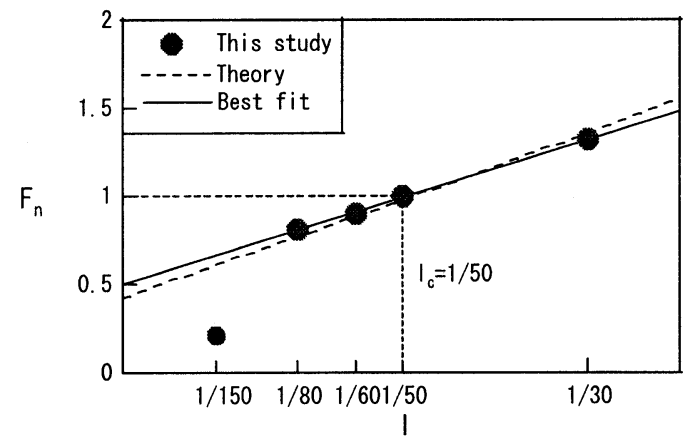

図 $4 \mathrm{~F}_{\mathrm{n}}$ とIとの関係

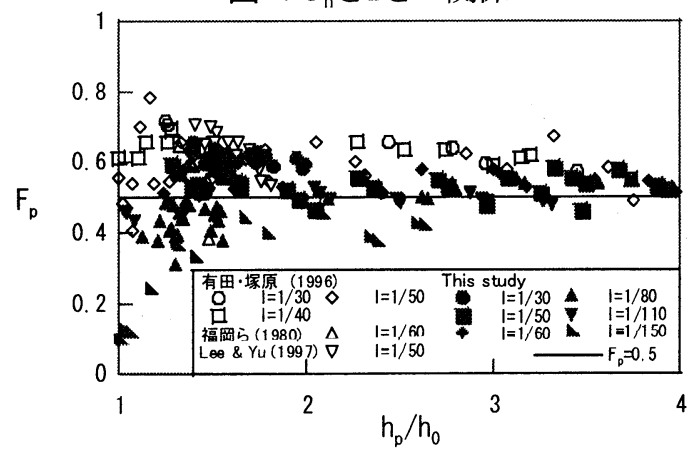

図-6 $\quad F_{p}$ と $h_{p} / h_{0}$ との関係
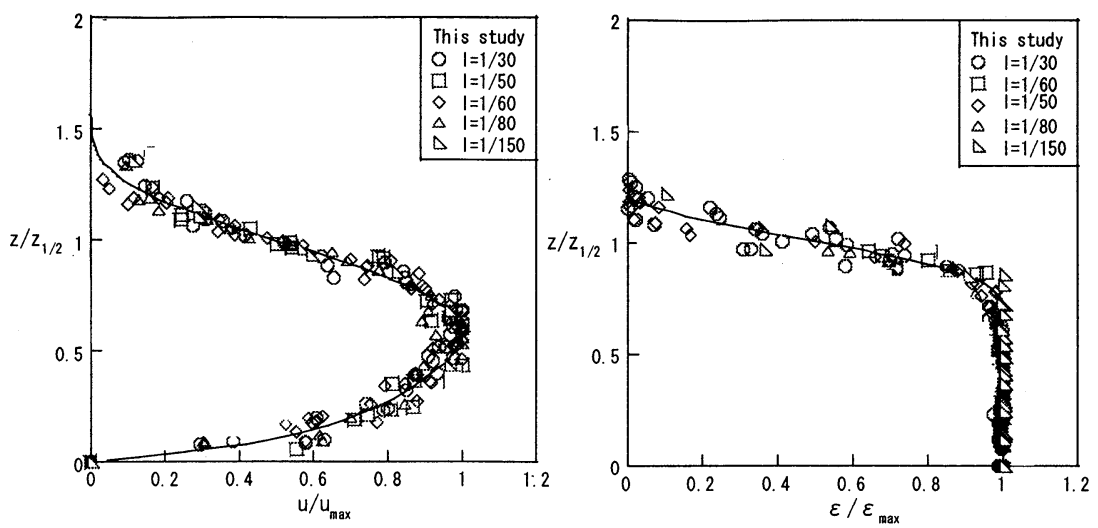

図-3下層密度流の流速分布と密度分布

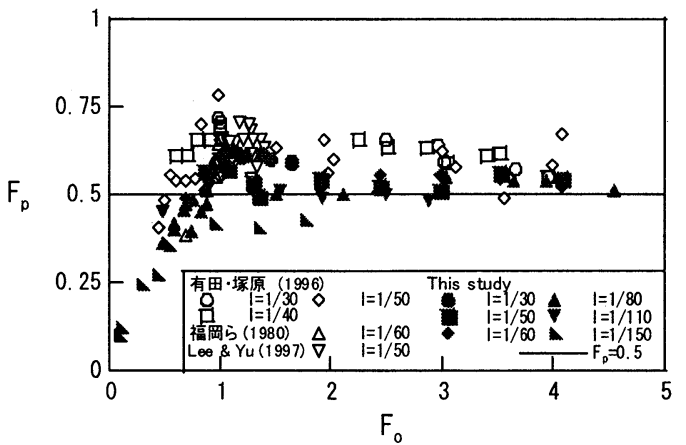

図-5 $\quad \mathrm{F}_{\mathrm{p}}$ と $\mathrm{F}_{0}$ との関係

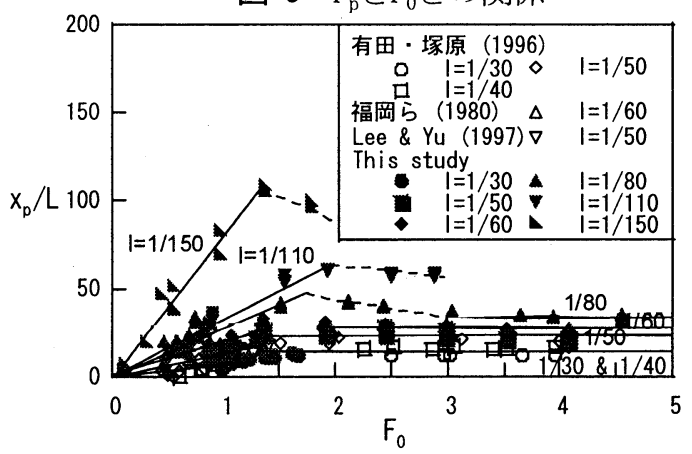

図-7 $\mathrm{x}_{\mathrm{p}} / \mathrm{L}$ と $\mathrm{F}_{0}$ との関係

$\mathrm{F}_{\mathrm{n}}=\frac{\mathrm{S}_{2} \mathrm{I}-\mathrm{S}_{1} \mathrm{E} / 2}{\mathrm{f}_{\mathrm{b}}+\mathrm{E}} \quad(7) \quad ; \quad \mathrm{E}=0.0009(\theta+5)$

図-4は，このようにして得られた $\mathrm{F}_{\mathrm{n}}$ と $\mathrm{I}$ との関係につ いて調べたものである. 図中の実線は，I=1/150のデー タを除いたベストフィットカーブであり, 式(6)で表さ れる. これを除外した理由は, 後述するように, 実験装 置の制約から必ずしも潜入領域下流端での正確な流速, 密度分布が得られていると確証できなかったからである.

$$
\mathrm{F}_{\mathrm{n}}=25 \mathrm{I}+0.5
$$

また，破線は以下で述べる1次元下層密度流の理論に 基づき得られた関係である。図-4より，限界勾配は $I_{c} \fallingdotseq 1 / 50$ であることが確認される。これは，著者らの データを除き，これまで得られた $\mathrm{F}_{\mathrm{p}}$ は急勾配あるいは限 界勾配に極めて近い緩勾配での值であり, 緩勾配でのF 值に関して有益な情報がほとんど得られていなかったこ とを意味している.1次元下層密度流の理論より, 発達 した下層密度流のFroude数 $F_{n}$ は式 (7) で与えられ，底面 傾斜角度 $\theta$ が $5^{\circ}$. 以上であれば, 連行係数巨と $\theta$ との関係 は, 式(8)で与えられる1)。

図-4には，両式より得られる $\mathrm{F}_{\mathrm{n}}$ と $\mathrm{I}$ との関係が示して ある。これより， $\mathrm{F}_{\mathrm{n}}$ と的の関係はおおよそ予測できる ことがわかる. ただし， $\theta<5^{\circ} \quad(\mathrm{I}<1 / 11.4)$ での下層密度 流のEとIとの関倸はわかっていないので，式(8)がこの 範囲でも成立すると仮定して算定した。 また, 形状係数 は上記の值を用い， $\mathrm{f}_{\mathrm{b}}$ は滑面水路を用いた室内実験結果 であることを踏まえ， $\mathrm{f}_{\mathrm{b}}=0.01$ とした。

図-5は，各水路床勾配ごとの $\mathrm{F}_{\mathrm{p}}$ と $\mathrm{F}_{0}$ との関係を示した ものである. 図中にはI $1 / 30$ の既往のデー夕も同時に プロットされている. $\mathrm{F}_{\mathrm{p}}$ が $\mathrm{F}_{0}$ とIによって大きく変化する

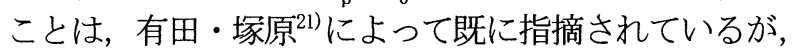
$\mathrm{F}_{0}$ が大きいところでの $\mathrm{F}_{\mathrm{p}}$ の挙動はわかっていない，また， 彼らの結果はI $=1 / 3 \sim 1 / 50$ の範囲での結果であり, 限界 勾配が $I_{c} \fallingdotseq 1 / 50$ であることからも明らかなように，緩勾 配水路での結果ではない. 図-5より次のことがわかる. $\mathrm{F}_{0} \fallingdotseq 1$. 0 以下，才なわち $\mathrm{h}_{0}$ が内部限界水深 $\mathrm{h}_{\mathrm{c}}$ より小さい場 


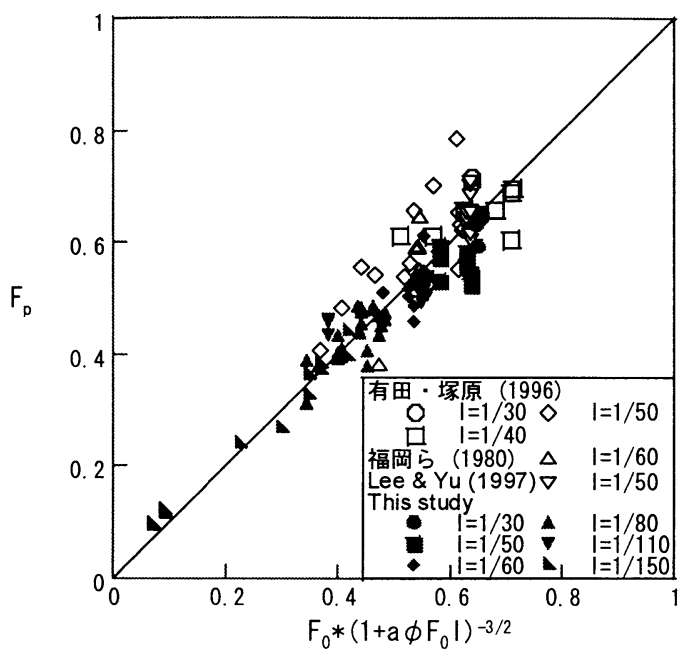

図-8 式 (11) の妥当性の検証

合は，水路床勾配にかかわらず， $\mathrm{F}_{\mathrm{p}}$ は増加する傾向があ る.また，急勾配水路では $\mathrm{F}_{0} \fallingdotseq 1.0$ で最大值を取るが， 緩勾配水路ではそうはならない， $\mathrm{F}_{0} \fallingdotseq 1.0$ 以上では，急 勾配水路での $\mathrm{F}_{\mathrm{p}}$ は， $\mathrm{F}_{0}$ が大きくなるにつれて最大值から 徐々に減少し, $\mathrm{F}_{\mathrm{p}} \fallingdotseq 0.5$ に漸近する。一方，緩勾配水路 でのF $\mathrm{F}_{\mathrm{p}}$ はF $\mathrm{F}_{0}$ が大きくなるにつれて徐々に増加し，やはり $\mathrm{F}_{\mathrm{p}} \fallingdotseq 0.5$ に漸近する. これは， $\mathrm{F}_{0}$ が大きくなると， $\mathrm{F}_{\mathrm{p}}$ は水 路形状の影響を受けない普遍的な值，つまり， $\mathrm{F}_{\mathrm{p}} \doteqdot 0.5$ となるためであると考えられる。－一方で替入するために は必ず $\mathrm{h}_{\mathrm{p}} / \mathrm{h}_{0} \geqq 1.0$ であるので, $\mathrm{F}_{0}$ が小さければF $\mathrm{F}_{\mathrm{p}}$ は限りな く0に近い值を取り得る。このため，潜入点付近の局所 的な流れの状態に基づく理論解析 ${ }^{8)}$,20) では， $\mathrm{F}_{0}$ とIの影 響を受ける範囲でのF $\mathrm{F}_{\mathrm{p}}$ を予測できないことになる．本研 究の結果に基づけば， $\mathrm{F}_{\mathrm{p}}$ が流入条件と水路形状の影響を 受ける範囲は, 緩勾配水路で $F_{0} \leqq 2.0$ 程度, 急勾配水路 では $\Gamma_{0} \leqq 4.0 \sim 5.0$ 程度であると考えられる.この範囲で の潜入水深を理論的に予測することは不可能であると考 えられるので，以下では実験結果に基づき検討を加える. まず，どのような条件下で $\mathrm{F}_{\mathrm{p}} \fallingdotseq 0.50$ 普遍的な関係が 成立するのかを明らかにする必要がある.この目的で各 水路床勾配ごとの $\mathrm{F}_{\mathrm{p}}$ と $\mathrm{h}_{\mathrm{p}} / \mathrm{h}_{0}$ との関係を調べたものが図-6 である.データのばらつきのため，各勾配ごとに評価す ることは難しいが，おおまかには，急勾配水路で $\mathrm{h}_{\mathrm{p}} / \mathrm{h}_{0} \fallingdotseq 4.0$, 緩勾配水路で $\mathrm{h}_{\mathrm{p}} / \mathrm{h}_{0} \fallingdotseq 2.0$ で流入条件と水路形 状の影響がほぼなくなるようである。.また，水路の幾何 学的形状より式(9) の関係があるので, 図-6でみた $h_{\mathrm{p}} / \mathrm{h}_{0}$ は $\mathrm{x}_{\mathrm{p}}$ とIで規定されている.ここに， $\mathrm{x}_{\mathrm{p}}=$ 流入点加ら潜入 点までの距離である. $\mathrm{h}_{\mathrm{p}} / \mathrm{h}_{0}$ を無次元距離 $\mathrm{x}_{\mathrm{p}} / \mathrm{h}_{0}$ で表すと, 急勾配水路で $\mathrm{x}_{\mathrm{p}} / \mathrm{h}_{0} \fallingdotseq 3 / \mathrm{I}$, 緩勾配水路で $\mathrm{x}_{\mathrm{p}} / \mathrm{h}_{0} \fallingdotseq 1 / \mathrm{I}$ となり, $\mathrm{F}_{\mathrm{p}} \fallingdotseq 0.5$ の関係が成立するのは, 流入点から相当離れた 地点であることがわかる.

$$
\mathrm{h}_{\mathrm{p}} / \mathrm{h}_{0}=1+\mathrm{x}_{\mathrm{p}} \mathrm{I} / \mathrm{h}_{0}
$$

有田 ${ }^{22)}$ は, flow force と buoyancy fluxの保存より 得られる長さスケール $\mathrm{L}\left(=\mathrm{h}_{0} \phi\right)$ を用いて, 潜入点まで の距離 $\mathrm{x}_{\mathrm{p}}$ について検討を加えている．ここに， $\phi=\mathrm{F}_{0}^{4 / 3}\left(1+0.5 \mathrm{~F}_{0}^{-2}\right)$ である. これと同様に, $\mathrm{x}_{\mathrm{p}} / \mathrm{L}$ と $\mathrm{F}_{0}$ と

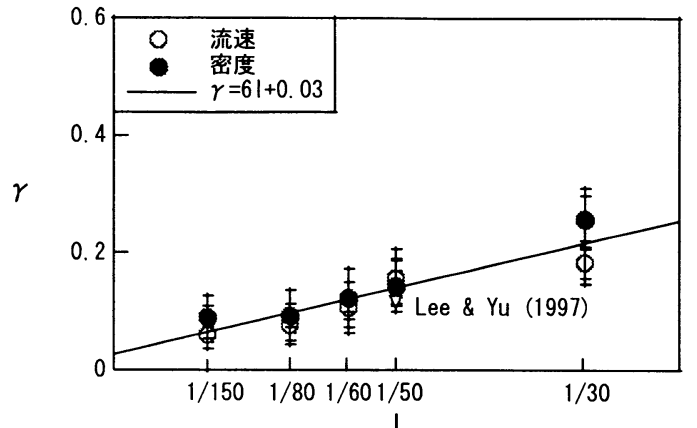

図-9 初期混合率 $\gamma$ と水路床勾配I との関係

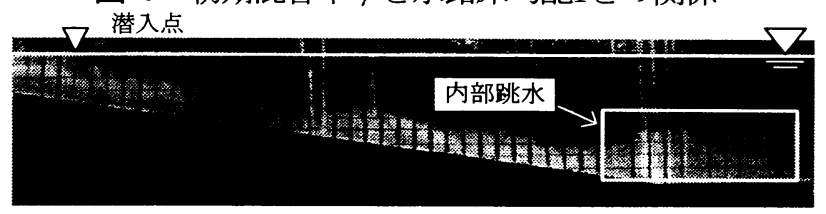

図-10 CASE Bの流動状況の一例(CASE B-2-4)

の関係を調べたものが図-7である．これより，次のこと がわかる．急勾配水路では， $\mathrm{F}_{0} \geqq$ 約 $1.0 て ゙ \mathrm{x}_{\mathrm{p}} / \mathrm{L}$ はほぼ一定 值を取るが，それ以下では $\mathrm{x}_{\mathrm{p}} / \mathrm{L}$ は増加率aでほぼ線形的 に増加する. 一方, 緩勾配水路では, $\mathrm{F}_{0}=0$ ～2.00範囲 で $x_{\mathrm{p}} / \mathrm{L}$ は線形的に増加し, 最大值を取った後に減少する. $\mathrm{F}_{0}=0$ ～2.00範囲での増加率aは水路床勾配に応じて変化 する. 図-7に基づけば，各水路床勾配Iでの増加率aは, $\mathrm{I}=1 / 30 ， 1 / 50 ， 1 / 60 ， 1 / 80 ， 1 / 110$ およ゙1/150で，それ

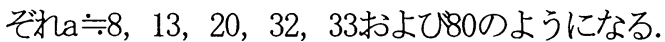

図-8は，式(9) と式(10)より得られる式(11)の妥当性 を検証した図であり，ほぼこの関係が成立していること が確認できる.

$$
\mathrm{x}_{\mathrm{p}} / \mathrm{L}=\mathrm{aF}_{0} \quad(10) \quad ; \quad \mathrm{F}_{\mathrm{p}} / \mathrm{F}_{0}=\left(1+\mathrm{a} \phi \mathrm{F}_{0} \mathrm{I}\right)^{-3 / 2}
$$

初期混合率 $\gamma$ につて検討を加える. 流速と塩分濃度 分布の両測定結果から得られた $\mathrm{q}_{n}$ に基づき算定された初 期混合率 $\gamma$ と水路床勾配I との関係について調べたもの が図-9である.データのばらつきは認められるが，いず れの測定結果からも $\gamma$ はIに依存していることが見て取 れる.これより，I=1/150〜1/30の範囲では， $\gamma$ は 式(12)で表せると考えられる. ただし，先述した理由か ら，I=1/150の $\gamma$ 值はやや傾向が異なっている．なお, 図中の矢印はエラーバーである. I=1/50でのLee \& $\mathrm{Yu}^{99}$ の結果は $\gamma \doteqdot 0.17$ となっており, 本研究で得られた $\gamma$ 值 とほぼ一致している.また, 式(6)と式(12)より, 先述 したFarre11 \& Stefan ${ }^{13)}$ の経験式と類似した関係式とし て, $\gamma \doteqdot 0.24\left(F_{n}-0.5\right)$ の関係が得られる.

$$
\gamma \doteqdot 0.03+6 \mathrm{I}
$$

\section{（2）成層型貯水池での潜入密度流(CASE B)}

成層I型ダム貯水池において流入水が潜入を経て，中 層密度流として躍層に沿って貫入する場合の潜入点につ いて若干の検討を加える. 図-10にCASE Bの流動状況の 一例を示す. 図-11は, CASE B の $\mathrm{F}_{\mathrm{p}}$ と $\mathrm{F}_{0}$ との関係につい て調べたものである. 図中には, CASE Bの水路床勾配が I=1/5であることを踏まえ, 有田・塚原 ${ }^{21)}$ こよって得ら 
れた，CASE Aの状況でのI=1/4〜1/7の範囲での実験結果 を示してある. これより，少なくとも $/ \mathrm{h}_{0}=3.0 \sim 10.6 の$ 範囲では, $\mathrm{h} / \mathrm{h}_{0}$ の影響は認められないようである.また, $\mathrm{F}_{0}$ の増加に伴い $\mathrm{F}_{\mathrm{p}}$ が減少する弱い傾向があるようにも見 て取れるが，明確ではない．いずれにせよ，全体的に $\mathrm{F}_{\mathrm{p}}=0.5$ よりやや大きい值を取っているが，有田・塚原に よるI $=1 / 5$ の結果を勘案すると, $\mathrm{F}_{0} \geqq$ 約 2.0 での $\mathrm{F}_{\mathrm{p}}$ 值の傾 向は，混合型貯水池と大きな違いがないようである．た だし， $\mathrm{F}_{0}$ がそれより小さいところでは， I=1/7の結果と 比較すると， $\mathrm{F}_{\mathrm{p}}$ 值は相当小さくなっている. 今回の実験 では斜面が急勾配であり, 図-10から明らかなように, そこでの流れが射流であり，斜面下端で内部跳水が発生 している.このため, 通常の潜入に伴う補償流のみなら ず，内部跳水に伴う同様な影響も考えられることから， 急勾配水路での内部跳水の影響や緩勾配での $F_{p}$ 值のふる まいなど，さらなる検討が必要であると考えられる。

\section{4. まとめ}

本研究より，以下のような結論が得られた。

(1) 混合型貯水池では, $\mathrm{F}_{\mathrm{p}}$ が流入条件 $\left(\mathrm{F}_{0}\right)$ と水路形状 $(\mathrm{I})$ の影響を受ける範囲は, 緩勾配水路で $0<\mathrm{F}_{0} \leqq 2.0$ 程度, 急勾配水路では $0<\mathrm{F}_{0} \leqq 4.0 \sim 5.0$ 程度である.この範囲 以外では, 潜入点の内部Froude数 $\mathrm{F}_{\mathrm{p}}$ は, $\mathrm{F}_{\mathrm{p}} \doteqdot 0.5$ の值を取 る. $\mathrm{F}_{0} \fallingdotseq 0 \sim 1.0$ での潜入点の内部Froude数 $\mathrm{F}_{\mathrm{p}}$ は, 式(11) で与えられる，その中間の $\mathrm{F}_{0}$ では各水路勾配に応じて変 化する。.また，初期混合率 $\gamma$ は式(12)で与えられる。 な お，限界公配、は約 $1 / 50$ である。

(2)成層型貯水池では， $\mathrm{F}_{0}$ が大きいところでは，混合型 貯水池での $\mathrm{F}_{\mathrm{p}}$ 值と大きな違いはない，しかし， $\mathrm{F}_{0}$ が小さ いところでの混合型貯水池の結果と比較すると， $F_{p}$ は小 さくなる．ただし，限られた条件下での結果であり，さ らなる検討が必要であると考えられる.

今後は，混合型貯水池において，流入条件や水路形状 が潜入密度流に及ぼす影響について検討を加えるととも に，室内実験では難しい条件での現象解明に向けて，数 值モデルの開発に取組む予定である.

\section{参考文献}

1) 秋山壽一郎：流入型密度流の水理特性とその予測，湖沼, 貯水地の管理に向けた富栄養化現象に関する学術研究のと りまとめ, 土木学会水理委員会, 環境水理部会, pp.69-167, 2000.

2) 久保直也ら: 風屋貯水池における淡水赤潮現象と貯水池環 境, 大ダム, No.126, pp.18-25, 1988.

3）畑 幸彦: 永瀬ダム湖（高知県）の淡水赤潮, 水質污濁研 究, Vol.14, No.5, pp.25-29, 1991

4) 中本信忠: 神流湖の淡水赤潮, 水質污濁研究, Vol.14, No.5, pp.13-17, 1991.

5) 山田正人，宗宮功，小野芳朗，小林尚礼：ダム貯水池にお けるPeridinium淡水赤潮の集積機構の評価, 水環境学会誌, 第18巻, 第10号, pp.775-783, 1995.

6) 松尾直規，山田正人，宗宮功：貯水地上流端における流動 特性と淡水赤潮現象との関係, 水工学論文集, 第 40 巻, pp.575-581, 1996.

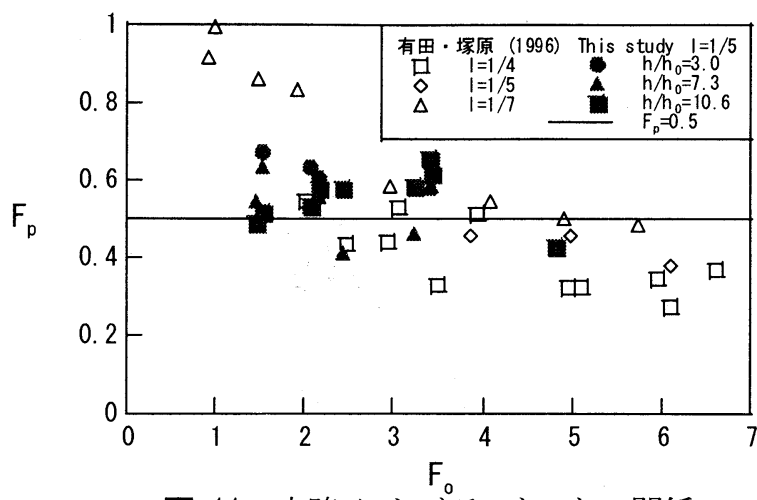

図-11 水路Bにおける $\mathrm{F}_{\mathrm{p}}$ と $\mathrm{F}_{0}$ との関係

7) 天野邦彦, 田中康泰, 鈴木宏明, 安田佳哉: 貯水池末端に おける持続的な淡水赤潮に関する研究，水工学論文集，第 44巻, pp.1083-1088, 2000.

8) 福岡捷二, 福嶋祐介, 中村健一：2 次元貯水池潜入密度流 の潜り込み水深と界面形状, 土木学会論文報告集, 第302 号, pp.55-65, 1980.

9) Lee, H.Y \& Yu, W.S.: Experimental study on reservoir turbidity current, $J$. of Hydraulic Engineering, ASCE, Vol.123, №.6, pp.520-528, 1997.

10) Elder, R.A. \& Wunderlich, W.O.: Inflow dernsity currents in TVD reservoirs, Int'l Symp. Stratified Flows, IAHR/ASCE, Novosibirks, USSR, pp.221-236, 1972.

11) Akiyama, J. \& Stefan, H.G. : Plunging flow into a reservoir: theory, J. of Hydraulic Engineering, ASCE, Vol.110, HY.4, pp.484-498, 1984.

12) Akiyama, J. \& Stefan, H.G.: Onset of undrflow in slightly diverging channels, J. of Hydraulic Engineering. ASCE, Vol.113, No.7, pp.825-844, 1987.

13) Farrell, G.J. \& Stefan, H.G.: Mathematical modeling of plunging reservoir flows, J. of Hydraulic Research, Vol.26, No.5, pp.525$537,1988$.

14) 秋山壽一郎, 西 恭太, 浦 勝 : 潜入密度流の流動特性と フェンスエによる流動制御,水工学論文集, 第47巻, pp.11771282(2003).

15) Singh, B. \& Shah, C.R. : Plunging phenomena of density currents in reservoirs, LaHouille Blanche, Vol.26, No.1, pp.59-64,1971.

16) Hebbert, $B$. et al.: Collie river underflow into the Wellington reservoir, J. of Hydraulic Engineering, ASCE, Vol.105, HY.5, pp.533-545, 1979.

17) Ford, D.F. et al.: Density inflows to Degray lake, Arkansas, Proc. of Second Int'l Symposium on Stratified Flows, Trondheim, Norway, pp.977-987, 1980.

18）菅 和利，玉井信行 : 貯水池潜入部の潜り点及び初期混合 に関する研究，第25回水理講演会論文集, pp.631-636, 1981.

19) Hauenstein, W. \& Dracos, T.H. :Investigation of plunging density currents generated by inflows in lakes, $J$. of Hydraulic Research, Vol.22, No.3, pp.157-179, 1984.

20) Savage, S.B. \& Brimberg, J.: Analysis of plunging phenomena in water reservoirs, $J$. of Hydraulic Research, Vol.13, No.2, pp.187204, 1975.

21）有田正光, 塚原千明 : 貯水池密度流の潜り点の水理条件に 関する実験的研究，ながれ，第15巻, pp.409-416, 1996.

22) 有田正光 : 貯水池密度流の潜り点の水理条件に関する解析 的研究, 水工学論文集, 第40巻, pp.567-574, 1996.

(2003. 9. 30受付) 